\title{
Western Blot Analysis of Chloroplast HSP70B in Chlorella Species
}

Stephka Chankova ${ }^{1 *}$, Zhana Mitrovska ${ }^{1}$ and Nadezhda Yurina ${ }^{2^{*}}$

${ }^{1}$ Ecosystem Research, Ecological Risk Assessment And Conservation Biology, Institute of

Biodiversity and Ecosystem Research, BAS, Sofia, Bulgaria; ${ }^{2}$ laboratory of Bioenergetics, A.N.

Bach Institute of Biochemistry RAS, Moscow, Russia

*For correspondence: Stephanie.Chankova@yahoo.com; NYurina@inbi.ras.ru

[Abstract] Western blotting allows for the specific detection of proteins by an antibody of interest. This protocol utilizes isolation of total proteins protocol for Chlorella vulgaris prior to gel electrophoresis. After electrophoresis, the selected antibodies are used to detect and quantify levels of chloroplast HSP70B.

\section{Materials and Reagents}

1. Species

Three Chlorella species were used: C. vulgaris, isolated from soil samples of Livingston Island, the South Shetland Archipelago, Antarctic; C. vulgaris strain 8/1, isolated in 1968 from thermal springs in the region of Rupite, Bulgaria, and cultivated in our laboratory since 1975 and Chlorella kesslery a mesophile, from the Trebon collection.

Cultivation

Chlorella species were cultivated on TAP (Tris Acetate Phosphate) medium under continuous light of $60 \mu \mathrm{mol} / \mathrm{m}^{2} / \mathrm{s}$ and a temperature of $23{ }^{\circ} \mathrm{C} \pm 0.1{ }^{\circ} \mathrm{C}$ in a Phytotron GC 400 growth chamber. The species were cultivated at this temperature because it is well known, that eurythermal algae, could be grown at a wide range of temperatures.

2. Rabbit polyclonal antibody HSP70B cytoplasmic (Agrisera, catalog number: AS06 175)

3. Goat anti-rabbit IgG(H\&l) HRP conjugated (Agrisera, catalog number: AS09 602)

4. Coomassie brilliant blue G 250

5. Orthophosphoric acid (Valerus, catalog number: $\mathrm{N} 4420$ )

6. Trichloroacetic acid (TCA)

7. Bovine serum albumin (BSA) (Applichem $\mathrm{GmbH}$, catalog number: 1391 0025)

8. Albumin fraction $\mathrm{V}(\mathrm{pH} 7.0)$

9. Medium Pure Nitrocellulose $(\mathrm{NCM})(0.45 \mu \mathrm{m})$ (Bio-Rad Laboratories, catalog number: 162-0115)

10. Filter paper

11. Sponge 
12. $4 \mathrm{CN}$ (4-chloro-naphthol) (Bio-Rad Laboratories, catalog number: N170-6535)

13. N,N' N' Tetramethylethylendiamine (TEMED) (Alfa Aesar, catalog number: N12536)

14. Laemmli sample buffer (see Recipes)

15. Reagent of Bradford (see Recipes)

16. $5 x$ Laemmli buffer (see Recipes)

17. Running buffer (see Recipes)

18. Transfer buffer (see Recipes)

19. SDS-PAGE gel (see Recipes)

20. $30 \%$ Acrylamide/ $N, N$ '-methylenebisacrylamide (AA/MBA) (see Recipes)

21. $10 \%$ SDS (see Recipes)

22. $10 \%$ Ammonium Persulfate (see Recipes)

23. $1.5 \mathrm{M}$ Tris $\mathrm{HCl}$ buffer ( $\mathrm{pH}$ 8.8) (see Recipes)

24. $1.0 \mathrm{M}$ Tris HCl buffer ( $\mathrm{pH} 6.8$ ) (see Recipes)

25. $4 \mathrm{M} \mathrm{NaCl}$ (see Recipes)

26. $1.0 \mathrm{M}$ Tris $\mathrm{HCl}$ buffer ( $\mathrm{pH} 7.5)$ (see Recipes)

27. $20 \%$ Tween 20 (see Recipes)

28. Blocking buffer (see Recipes)

29. Staining solution (see Recipes)

30. $5 \% \mathrm{CH}_{3} \mathrm{COOH}$ (see Recipes)

31. Washing solution (see Recipes)

32. $50 \mathrm{mM}$ TBS-T buffer (see Recipes)

33. HRP color development solution (see Recipes)

\section{Equipment}

1. Motor

2. Silica quartz sand $0.6 \mathrm{~mm}$ (Valerus, catalog number: $\mathrm{N} 1760$ )

3. Centrifuge (Sigma-Aldrich, model: 1-15 K)

4. Electrophoresis chamber Transfer unit Hoefer miniVE electrophoresis and electrotransfer unit (Hoefer, model: SE300-10A-1.0)

5. Mini Rocker Shaker MR-1

\section{Software}

1. Image J program 


\section{Procedure}

A. Cells lysis

1. Add $100 \mu$ l Lysys Solution (LS) to the pellet (Chankova et al., 2013b) transfer to a chilled mortar, add two spatulas of silica sand, grind in the mortar for 3 min, add $200 \mu \mathrm{LS}$ in the mortar to wash and transfer the material into an Eppendorf tube of $2 \mathrm{ml}$.

2. Centrifuge material from step 1 for $10 \mathrm{~min}$ at $14,500 \times \mathrm{g}$.

3. Separate the supernatant and heat the supernatant for $5 \mathrm{~min}$ at $\mathrm{t}=90^{\circ} \mathrm{C}$.

4. Centrifuge for $5 \mathrm{~min}$ at $14,500 \times \mathrm{g}$.

5. Split the supernatant in 2 samples: The first one use for the determination of protein concentration; the second one keep at $\mathrm{t}=-20^{\circ} \mathrm{C}$.

B. Determination of protein concentration (Bradford)

1. Add $30 \mu \mathrm{l} 20 \%$ TCA to $30 \mu \mathrm{l}$ supernatant.

2. Centrifuge for $5 \mathrm{~min}$ at $14,500 \times \mathrm{g}$.

3. Add $60 \mu \mathrm{l} 0.1 \mathrm{~N} \mathrm{NaOH}$ to the pellet and mix thoroughly. To obtain best result add twice $30 \mu \mathrm{l}$ of $0.1 \mathrm{~N} \mathrm{NaOH}$.

4. Take $14 \mu \mathrm{l}$, add $86 \mu \mathrm{l} 0.15 \mathrm{M} \mathrm{NaCl}$ and $3 \mathrm{ml}$ reagent of Bradford.

5. Use calibration curve for quantity of protein (Table 1).

For calibration curve:

Stock solution $-0.5 \mathrm{mg} / \mathrm{ml} \mathrm{BSA}$

Use Table 1 to determine every point of standard curve add $3 \mathrm{ml}$ reagent of Bradford. 
Table 1. Calibration curve for quantity of protein

\begin{tabular}{|l|l|l|l|}
\hline $\mathrm{N}$ & $\mathrm{BSA}(\mu \mathrm{g})$ & $\begin{array}{l}\mathrm{BSA}(0.5 \mathrm{mg} / \mathrm{ml}) \\
\text { vol }(\mu \mathrm{l})\end{array}$ & $\begin{array}{l}\mathrm{NaCl}(0.15 \mathrm{M}) \\
\mathrm{vol}(\mu \mathrm{l})\end{array}$ \\
\hline 1. & 0 & 0 & 100 \\
\hline 2. & 5 & 10 & 90 \\
\hline 3. & 10 & 20 & 80 \\
\hline 4. & 15 & 30 & 70 \\
\hline 5. & 20 & 40 & 60 \\
\hline 6. & 25 & 50 & 50 \\
\hline 7. & 30 & 60 & 40 \\
\hline 8. & 35 & 70 & 30 \\
\hline 9. & 40 & 80 & 20 \\
\hline 10. & 45 & 90 & 10 \\
\hline 11. & 50 & 100 & 0 \\
\hline
\end{tabular}

C. Protein electrophoresis

1. Put about $100 \mathrm{ml}$ of the $1 x$ Laemmli buffer into cuvettes of electrophoresis module.

2. Remove the comb and rinse the wells with buffer of SDS-PAGE gel.

3. Pipet $10 \mu \mathrm{g}$ protein into every well: adjust volumes so equal amount of protein is loaded (example: $10 \mu \mathrm{g}$ protein are contained in $10 \mu$ sample).

4. Put the rest buffer in a bath of electrophoresis chamber (the volume must be always above minimum).

5. Run electrophoresis using the following parameters: $120 \mathrm{~V}$ and $16 \mathrm{~mA}$ for $3.5 \mathrm{~h}$.

6. When the electrophoresis is completed, remove the gel carefully.

Note: The order of the dropping of the samples. Concentrated gel should be released.

D. Transfer of proteins on the NCM

1. Soak the gel for $15 \mathrm{~min}$ in buffer.

2. Soak sponge and filter paper for sandwich in transfer buffer.

3. Cut NCM. The size should be such as the size of the gel. Put NCM for 5 min in transfer buffer.

Note: Mark the order of samples on the membrane! Label the membrane with a pencil.

4. Make a sandwich.

a. The stack is assembled on the black cathode side (see Figure 1):

i. Center a packing sponge on the black cathode side.

ii. Center a packing sponge on the black catode (a).

iii. Lay one piece of wet filter paper on the sponge (b). 
iv. Position the equilibrate gels on the filter paper(c).

v. Lay the membrane on the gel (d).

vi. Lay one piece of wet filter paper on the membrane (e).

vii. Lay two packing sponges on the filter paper (f).

viii. A second transfer stack if added, is placed between these two sponges.

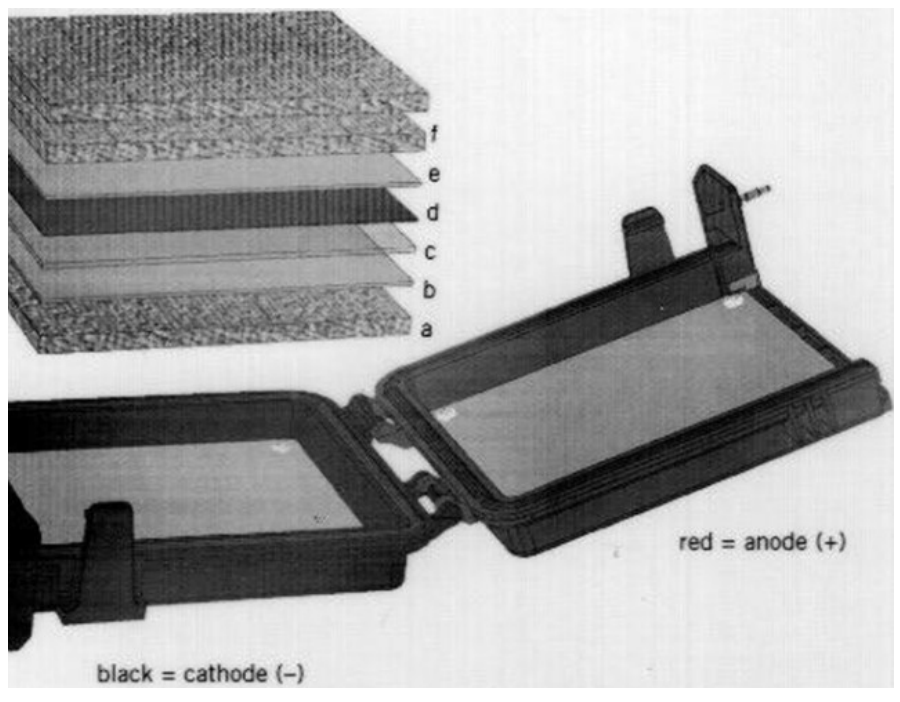

Figure 1. Assembling a transfer stack (this is an original figure taken from the Technical Guide available at www. hoeferinc.com)

b. Different parts of the sandwich press very well, to avoid bubbles.

c. Different parts of the sandwich should be well moistened. You can "roll" them with a tube.

i. Close the apparatus. Put in a chamber transfer buffer.

ii. Run blotting with the following parameters: $35 \mathrm{~V}$ and $250 \mathrm{~mA}$ for $2 \mathrm{~h}$.

E. Western blot

1. After the transfer of proteins, place the membrane in blocking buffer at $t=4{ }^{\circ} \mathrm{C}$. Incubate on a rocker platform for $1 \mathrm{~h}$ (following this step we have obtained the best results).

2. Place gels in staining solution for $4-5 \mathrm{~h}$.

3. Wash for 3-4 $\mathrm{h}$ the gel with washing solution.

4. Dilute primary antibody in blocking buffer $(1: 10,000)$ and incubate according to manufacturer's instructions. Incubate on a rocker platform at $\mathrm{t}=4{ }^{\circ} \mathrm{C}$ overnight.

5. Wash the membrane in TBS-T buffer on a rocker platform in a following way: twice for 2 $\min (2 \times 2 \mathrm{~min})$, after that twice for $10 \min (2 \times 10 \mathrm{~min})$. 
6. Prepare secondary antibody in blocking buffer $(1: 20,000)$ and incubate according to manufacturer's instructions. Incubate on a rocker platform at RT for $2 \mathrm{~h}$.

7. Wash the membrane in TBS-T buffer on a rocker platform in a following way: Twice for 2 $\min (2 \times 2 \mathrm{~min})$, after that three times for $5 \min (3 \times 5 \mathrm{~min})$.

8. Visualize using HRP Color Development Solution, $4 \mathrm{CN}$ according manufacturer's instructions.

9. Scan the membrane. Calculate protein amount using Image J program.

\section{$\underline{\text { Recipes }}$}

1. Laemmli sample buffer

$2 \%$ SDS

$5 \%$ 2-mercaptoehtanol

$10 \%$ glycerol

$0.002 \%(\mathrm{w} / \mathrm{v})$ bromophenol blue

$62.5 \mathrm{mM}$ Tris $\mathrm{HCl}(\mathrm{pH} 6.8)$

2. Reagent of Bradford

Dissolve $100 \mathrm{mg}$ Coomassie brilliant blue G 250 and $50 \mathrm{ml} \mathrm{96 \%} \mathrm{alcohol} \mathrm{in} \mathrm{a} \mathrm{stirrer} \mathrm{for} 15$ min. Add $94.5 \mathrm{ml} 90 \%$ orthophosphoric acid.

Add $900 \mathrm{ml}$ deionized $\mathrm{H}_{2} \mathrm{O}$ and stir gently.

Filtering through a folded filter paper and make up to $1 \mathrm{~L}$ with deionized water.

Keep in a fridge at $\mathrm{t}=4^{\circ} \mathrm{C}$.

3. $5 x$ Laemmli buffer

$15 \mathrm{~g}$ TRIS base

$72 \mathrm{~g}$ Glycine in $1 \mathrm{~L}$ deionized $\mathrm{H}_{2} \mathrm{O}$

4. Running Buffer

Add $200 \mathrm{ml} 5 \mathrm{x}$ Laemmli buffer $+10 \mathrm{ml} 10 \%$ SDS to $1 \mathrm{~L}$ deionized $\mathrm{H}_{2} \mathrm{O}$

5. Transfer Buffer

Add $200 \mathrm{ml} 5 \mathrm{x}$ Laemmli buffer $+2 \mathrm{ml} 10 \%$ SDS to $+200 \mathrm{ml}$ ethanol to $1 \mathrm{~L}$ deionized $\mathrm{H}_{2} \mathrm{O}$

6. SDS-PAGE gel

Note: Glass tiles should be cleared well with alcohol before preparing SDS-PAGE gel.

a. Separating gel (12.5\%) (Table 2$)$ 
Table 2. Preparing of separating gel solution

\begin{tabular}{|l|l|l|}
\hline Number of mini-gels & 1 & 2 \\
\hline Deionized $\mathrm{H}_{2} \mathrm{O}$ & $3.2 \mathrm{ml}$ & $6.4 \mathrm{ml}$ \\
\hline Acrilamide/bisacrilamide $(30 \%)$ & $4 \mathrm{ml}$ & $8.0 \mathrm{ml}$ \\
\hline $1.5 \mathrm{M}$ Tris $\mathrm{HCl}$ buffer, $\mathrm{pH} 8.8$ & $2.6 \mathrm{ml}$ & $5.2 \mathrm{ml}$ \\
\hline $10 \%$ SDS & $100 \mu \mathrm{l}$ & $200 \mu \mathrm{l}$ \\
\hline $10 \%$ APS & $100 \mu \mathrm{l}$ & $200 \mu \mathrm{l}$ \\
\hline TEMED & $10 \mu \mathrm{l}$ & $20 \mu \mathrm{l}$ \\
\hline
\end{tabular}

i. Mix very carefully the components in a $50 \mathrm{ml}$ Falcon tube to avoid bubbles.

ii. Insert separating gel between two glass plates of the chamber (about $1 \mathrm{~cm}$ below the boundary of tiles).

iii. Add deionized $\mathrm{H}_{2} \mathrm{O}$ carefully as a thin film using a syringe and wait about 15 $\min$.

iv. Carefully remove the water; Wipe the water drops in the ends with filter paper.

b. Stacking gel (Table 3)

Table 3. Preparing of $4 \%$ stacking gel solution

\begin{tabular}{|l|l|l|}
\hline Number of mini-gels & 1 & 2 \\
\hline Deionized $\mathrm{H}_{2} \mathrm{O}$ & $1,370 \mu \mathrm{l}$ & $2,740 \mu \mathrm{l}$ \\
\hline Acrilamide/bisacrilamide $(30 \%)$ & $330 \mu \mathrm{l}$ & $660 \mu \mathrm{l}$ \\
\hline $1.0 \mathrm{M}$ Tris $\mathrm{HCl}$ buffer, $\mathrm{pH} 6.8$ & $250 \mu \mathrm{l}$ & $500 \mu \mathrm{l}$ \\
\hline $10 \%$ SDS & $20 \mu \mathrm{l}$ & $40 \mu \mathrm{l}$ \\
\hline $10 \%$ APS & $20 \mu \mathrm{l}$ & $40 \mu \mathrm{l}$ \\
\hline TEMED & $2 \mu \mathrm{l}$ & $4 \mu \mathrm{l}$ \\
\hline
\end{tabular}

c. Put the concentrated gel, insert the comb and wait until the gel polymerize.

d. For an electrophoresis is better to prepare about 1,250 $\mathrm{ml} \mathrm{1x}$ Laemmli buffer. It can be used twice.

7. $30 \%$ AA/MBA

$29.0 \mathrm{~g}+1.0 \mathrm{~g}$ MBA dissolve in $72.5 \mathrm{ml}$ deionized $\mathrm{H}_{2} \mathrm{O}$, make up the volume to $100 \mathrm{ml}$, filter using $0.45 \mu \mathrm{m}$ filter

Keep at $\mathrm{t}=4{ }^{\circ} \mathrm{C}$ less than 1 month.

8. $10 \%$ SDS

Dissolve $10 \mathrm{~g}$ SDS in $100 \mathrm{ml}$ deionized $\mathrm{H}_{2} \mathrm{O}$

9. $10 \%$ Ammonium Persulfate 
Dissolve $1 \mathrm{~g}$ in $10 \mathrm{ml}$ deionized $\mathrm{H}_{2} \mathrm{O}$

Keep at $\mathrm{t}=4^{\circ} \mathrm{C}$ less than 1 month.

10. $1.5 \mathrm{M}$ Tris $\mathrm{HCl}$ Buffer $\mathrm{pH} 8.8$

Dissolve $18.5 \mathrm{~g}$ Tris base in $80 \mathrm{ml}$ deionized $\mathrm{H}_{2} \mathrm{O}$, adjust to $\mathrm{pH}=8.8$ with concentrated $\mathrm{HCl}$ and make up the volume to $100 \mathrm{ml}$.

11. $1.0 \mathrm{M}$ Tris $\mathrm{HCl}$ Buffer $\mathrm{pH} 6.8$

Dissolve $12.114 \mathrm{~g}$ Tris base in $80 \mathrm{ml}$ deionized $\mathrm{H}_{2} \mathrm{O}$, adjust to $\mathrm{pH}=6.8$ with concentrated $\mathrm{HCl}$ and make up the volume to $100 \mathrm{ml}$.

12. $50 \mathrm{mM}$ TBS-T buffer

1.0 M Tris $\mathrm{HCl}$ buffer ( $\mathrm{pH} 7.5)$

$200 \mathrm{mM} \mathrm{NaCl}$

$0.1 \%$ Tween 20

13. $4 \mathrm{M} \mathrm{NaCl}$

Dissolve $23.376 \mathrm{~g} \mathrm{NaCl}$ in $100 \mathrm{ml}$ deionized $\mathrm{H}_{2} \mathrm{O}$

14. $1.0 \mathrm{M}$ Tris $\mathrm{HCl}$ buffer $(\mathrm{pH} 7.5)$

Dissolve $12.114 \mathrm{~g}$ TRIS base in $80 \mathrm{ml}$ deionized $\mathrm{H}_{2} \mathrm{O}$, adjust to $\mathrm{pH} 7.5$ with concentrated $\mathrm{HCl}$ and make up to the $100 \mathrm{ml}$.

15. $20 \%$ Tween 20

$20 \mathrm{ml}$ Tween make up to $100 \mathrm{ml}$ deionized $\mathrm{H}_{2} \mathrm{O}$.

16. Blocking buffer

Dissolve $5 \%$ fatless dry milk in $100 \mathrm{ml}$ TBS-T buffer.

17. Staining solution

$0.2 \%$ Coomassie Brilliant blue R- 250

$40 \% \mathrm{C}_{2} \mathrm{H}_{5} \mathrm{OH}$

18. $5 \% \mathrm{CH}_{3} \mathrm{COOH}$

Dissolve $2 \mathrm{~g}$ Coomassie Brilliant blue R- 250, $400 \mathrm{ml} \mathrm{C}_{2} \mathrm{H}_{5} \mathrm{OH}$ and $50 \mathrm{ml} \mathrm{CH} \mathrm{CHOOH}_{3} \mathrm{Cnd}$ make up to $1 \mathrm{~L}$ with deionized $\mathrm{H}_{2} \mathrm{O}$.

19. Washing solution

$40 \% \mathrm{C}_{2} \mathrm{H}_{5} \mathrm{OH}$

$5 \% \mathrm{CH}_{3} \mathrm{COOH}$

20. HRP Color Development Solution

Dissolve $60 \mathrm{mg}$ of 4-chloro-naphtol into $20 \mathrm{ml}$ of methanol.

Dissolve immediately before use and protect solution from light.

Immediately prior to use, add $60 \mu \mathrm{l}$ of ice cold $30 \% \mathrm{H}_{2} \mathrm{O}_{2}$ to $100 \mathrm{ml}$ TBS. Mix both solutions at RT. Use immediately. 


\section{References}

1. Chankova, S., Mitrovska, Z., Miteva, D., Oleskina, Y. P. and Yurina, N. P. (2013a). Heat shock protein HSP70B as a marker for genotype resistance to environmental stress in Chlorella species from contrasting habitats. Gene 516(1): 184-189.

2. Chankova, S., Mitrovska, Z. and Yurina, N. (2013b). Heat Shock Treatment of Chlamydomonas reinhardtii and Chlorella Cells. Bio-protocol 3(15): e849.

3. Chankova, S. G., Yurina, N. P., Dimova, E. G., Ermohina, O. V., Oleskina, Y. P., Dimitrova, M. T. and Bryant, P. E. (2009). Pretreatment with heat does not affect doublestrand breaks DNA rejoining in Chlamydomonas reinhardtii. $J$ Thermal Biol 34(7): 332336. 